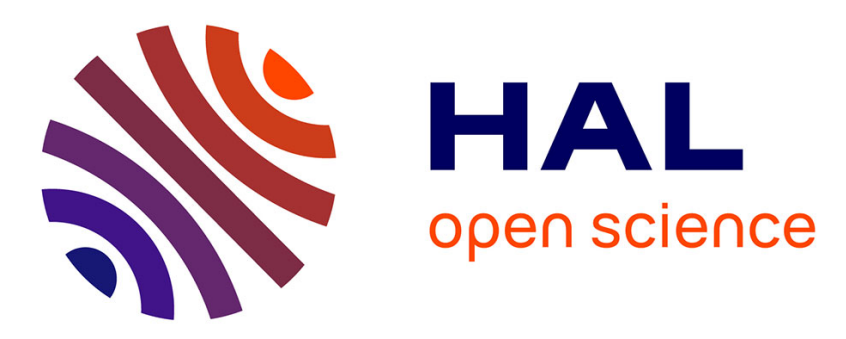

\title{
$89 \%$ reduction of a potato cyst nematode population using biological control and rotation
}

\author{
Daniel López-Lima, Petra Sánchez-Nava, Gloria Carrión, Angel \\ Núñez-Sánchez
}

\section{- To cite this version:}

Daniel López-Lima, Petra Sánchez-Nava, Gloria Carrión, Angel Núñez-Sánchez. 89 \% reduction of a potato cyst nematode population using biological control and rotation. Agronomy for Sustainable Development, 2013, 33 (2), pp.425-431. 10.1007/s13593-012-0116-7 . hal-01201359

\section{HAL Id: hal-01201359 \\ https://hal.science/hal-01201359}

Submitted on 17 Sep 2015

HAL is a multi-disciplinary open access archive for the deposit and dissemination of scientific research documents, whether they are published or not. The documents may come from teaching and research institutions in France or abroad, or from public or private research centers.
L'archive ouverte pluridisciplinaire HAL, est destinée au dépôt et à la diffusion de documents scientifiques de niveau recherche, publiés ou non, émanant des établissements d'enseignement et de recherche français ou étrangers, des laboratoires publics ou privés. 


\title{
$89 \%$ reduction of a potato cyst nematode population using biological control and rotation
}

\author{
Daniel López-Lima • Petra Sánchez-Nava • \\ Gloria Carrión • Angel Enrique Núñez-Sánchez
}

Accepted: 6 September 2012 /Published online: 4 October 2012

(C) INRA and Springer-Verlag, France 2012

\begin{abstract}
A major issue of potato cultivation in temperate zones is the potato cyst nematode Globodera rostochiensis. Population density of G. rostochiensis is high in Mexican potato fields. Control currently consists of the inefficient application of high doses of chemical nematicides. We evaluated the population density of G. rostochiensis in potato production plots in central Veracruz, Mexico. Plots were treated with the biocontrol agent Paecilomyces sp. and rotation with two different leguminous crop plants, Pisum sativum and Vicia faba. A random block experimental design was used with four different treatments over two crop cycles: (1) biological control with crop rotation, (2) crop rotation only, (3) biological control applied to soil left in fallow, and (4) soil left in fallow only. We measured the number and content of cysts, and the number of $\mathrm{J} 2$ juveniles of $G$. rostochiensis in the soil. We then estimated the infestation level in soil and the multiplication rate $(\mathrm{Pf} / \mathrm{Pi})$. The number of free-living nematodes was also quantified. Results show that the highest mitigation of G. rostochiensis was observed for the biological control rotation, with $89.2 \%$ reduction, and for the biological control fallow treatments with $84.4 \%$ reduction. In rotation plots, infestation level decreased by $30.7 \%$. In the biological control rotation and biological control fallow treatments, the $\mathrm{Pf} / \mathrm{Pi}$
\end{abstract}

D. López-Lima · P. Sánchez-Nava

Universidad Autónoma del Estado de México,

Unidad San Cayetano de Morelos,

50000, Toluca, Estado de México, México

\section{G. Carrión $(\bowtie)$}

Instituto de Ecología, A.C.,

Carretera Antigua a Coatepec 351,

91070, Xalapa, Veracruz, México

e-mail: gloria.carrion@inecol.edu.mx

\section{A. E. Núñez-Sánchez}

Facultad de Ciencias Agrícolas, Universidad Veracruzana, Circuito Gonzalo Aguirre Beltrán s/n Col. Lomas del Estadio, 91090, Xalapa, Veracruz, México was 0.1 and 0.15 , respectively. The highest $\mathrm{Pf} / \mathrm{Pi}$ of 0.93 was found in the fallow plots. The biological control agent did not significantly affect the free-living nematode populations. In this study, the nematophagous fungus Paecilomyces sp. was used for the first time to efficiently reduce the population of G. rostochiensis in two crop cycles.

Keywords Potato cyst nematode - Golden nematode . Integrated management $\cdot$ Nematophagous fungi

\section{Introduction}

The potato cyst nematode Globodera rostochiensis (Woll. 1923) Skarbilovich, 1959 is considered to be a pest of great economic significance to the cultivation of Solanum tuberosum worldwide (van Riel and Mulder 1998). It is estimated to account for up to $83 \%$ of losses in susceptible potato crops in temperate zones (Cunha et al. 2004; Franco 1994). Once established in the fields, it is very difficult to eliminate due to its high multiplication rate (Desgarennes et al. 2006; Turner 1996).

The main symptoms of infection are yellowing and hydric stress (EPPO 2009). When juveniles in the infective stage (J2) enter the root, they move through the cortex, dissolving the cell walls. They subsequently become sedentary (Fig. 1a, b), forming feeding sites known as syncytia (Sobczak and Golinowski 2011).

In Mexico, the potato cyst nematode is found in nine states and is responsible for estimated annual potato production losses of up to $70 \%$ (Brodie 1998; Tovar et al. 2006). In order to avoid the introduction, establishment, and dispersal of G. rostochiensis to new cultivation areas, several phytosanitary measures have been implemented. These prevent farmers in infested sites from selling their product as seed; however, the authorities have no control to stop movement of the infected tubers, and this has allowed the dispersal of 


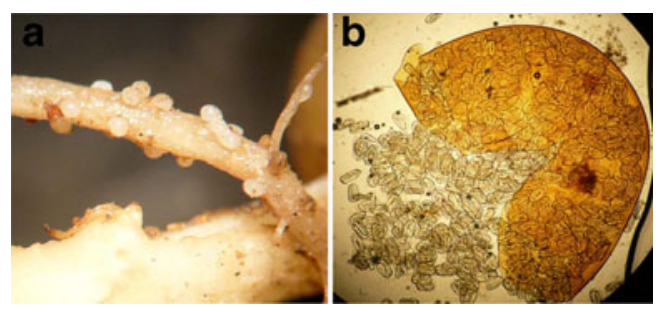

Fig. 1 Globodera rostochiensis a females in potato roots, b eggs within a cyst

this nematode to new areas (Núñez-Sánchez et al. 2003; SAGARPA 2002). Combat of the potato cyst nematode involves the application of chemical nematicides of the carbamate group (e.g., carbofuran, aldicarb, oxamyl); however, this nematicide application has not resulted in a reduced population of G. rostochiensis (Desgarennes et al. 2006). Moreover, due to the high mobility of these chemicals in the soil, there are many problems associated with their use; these include their negative effect on beneficial organisms (Haydock et al. 2006) and the fact that they can contaminate groundwater, and because of their residual effect (120 days), they can remain in the tuber until after harvesting, representing a risk not only to the farmers who apply these chemicals in the fields but also to the end consumers of the product (Mendes et al. 2005).

In the region of Cofre de Perote in Veracruz, Mexico, chemical control has produced poor results, and as a consequence of the potato monoculture, populations of this nematode have increased in some fields to more than 6,000 cysts $\mathrm{kg} \mathrm{soil}^{-1}$ since initial detection in 1983 (Desgarennes et al. 2006). These values surpass the tolerance limit of 40 cysts kg soil ${ }^{-1}$ at which the nematode is considered to have no effect on crop yield (EPPO 1996). For this reason, the implementation of integrated management that includes the control of this pest with agroecological methods such as biological control and crop rotation has been suggested (Lichtfouse et al. 2009).

Integrated management can favor the control of pests through the combination of diverse control methods, since this enhances the efficacy of each method on its own (Gurr et al. 2004). This study evaluated, over two crop cycles, the effect of the combination of two control strategies (biological control and crop rotation) to reduce a population density of $G$. rostochiensis. The fungus Paecilomyces sp. was used as a biological control agent for the first time in the experimental plots, and species identification was corroborated using genetic sequences. This fungus was isolated in specimens of $G$. rostochiensis in the study area, and its pathogenicity has been demonstrated in vitro. Furthermore, this fungus is the subject of a patent of use, which is currently in process (PCT-MX 2012000032). Pisum sativum and Vicia faba were used as (non-host) rotation crops.

\section{Materials and methods}

\subsection{Study area}

The study was conducted in the community of Los Pescados, in the municipality of Perote, in Veracruz, Mexico $\left(19^{\circ}\right.$ $33^{\prime} 41^{\prime \prime} \mathrm{N}, 97^{\circ} 08^{\prime} 53^{\prime \prime} \mathrm{W}, 2,980 \mathrm{~m}$ above sea level), over two spring-summer crop cycles (April-October 2010 and 2011).

\subsection{Experimental design}

Twenty experimental plots of $50 \mathrm{~m}^{2}$ were established in random blocks in a site with a high soil infestation of $G$. rostochiensis and subjected to four treatments with five replicates each: application of the biological control agent with peas (P. sativum) sown as a rotation crop in the springsummer cycle of 2010 and beans $(V . f a b a)$ in the 2011 cycle; the second treatment consisted of rotation only with no application of biological control; the third treatment consisted of application of the biological control agent and letting the soil lie fallow; the fourth treatment consisted of letting the soil lie fallow only with no application of the biological control. No tillage or weeding was carried out in either of the two fallow treatments. Potato plants remaining from the previous crop cycle were removed from all the plots. The rotation and fallow plots were used as controls of the cultivated and fallow plots, respectively. For those plots sown with peas, the variety "Canadiense" was used at a density of 180 plants per plot, and for beans, the variety "Major" was used at a density of 108 plants per plot. The nematophagous fungus Paecilomyces sp. was used as the biological control agent and was applied 10 days prior to sowing and at the time of sowing, in each crop cycle, with one further application made between the two crop cycles.

\subsection{Inoculum preparation}

The fungus was allowed to reproduce in a liquid medium until reaching a concentration of $2 \times 10^{7}$ spores $\mathrm{ml}^{-1}$. The resulting suspension of spores was made up to $4 \mathrm{~L}$ with tap water and applied directly to the soil with a manual spray pump. Application dose was $4 \times 10^{10}$ spores per plot.

\subsection{Population density of G. rostochiensis and free-living nematodes}

In each plot, composite soil samples were taken, comprising five subsamples (each of $500 \mathrm{ml}$ ). Eight such composite samples were taken throughout the experiment $(N=160)$, samples 1 to 4 taken during the first crop cycle (pea) with samples 5 to 8 taken in the second cycle (bean). In each cycle, the first sample was taken 10 days prior to sowing; the second was taken at the time of sowing and the rest at 60 
and 120 days after sowing. All samples were taken following a zig-zag pattern throughout each plot.

The cysts were obtained using the Fenwick can (1940) technique while nematodes were extracted from the soil using the sieve-centrifuge technique (s'Jacob and van Bezooijen 1984) (100 $\mathrm{ml}$ of soil in each technique). To determine the cyst content, the juveniles (J2) and eggs within the cysts were quantified. The emerged J2 of $G$. rostochiensis and free-living nematodes in the soil were fixed and transferred to glycerin, following the Seinhorst (1962) method.

G. rostochiensis was the only phytoparasitic nematode considered since in previous studies, it was shown to be the dominant species of potato crops in the study area (Desgarennes et al. 2009). In each plot, the number of cysts, their contents (eggs and J2 per cyst), and emerged $\mathrm{J} 2$ juveniles extracted from the soil were quantified in order to estimate the infestation level of G. rostochiensis: (number of juveniles and eggs $100 \mathrm{ml}$ soil $^{-1}$ )=average cyst content $\times$ number of cysts $+\mathrm{J} 2100 \mathrm{ml} \mathrm{soil}{ }^{-1}$. Initial population $(\mathrm{Pi})$ and final population $(\mathrm{Pf})$ values of both G. rostochiensis and free-living nematodes in all treatments were used to establish the multiplication rate $(\mathrm{Pf} / \mathrm{Pi})=$ final nematode population/initial nematode population.

\subsection{Statistical analysis}

Because the data obtained did not conform to assumptions of normality (Shapiro-Wilk's test) or to equality of variance (Levene's test), they were analyzed with the non-parametric Kruskal-Wallis $(H, P \leq 0.01)$ test and a multiple comparison test to compare between all the treatments, as well as the Wilcoxon $T$ test (Tw, $P \leq 0.05$ ) to compare the initial and final populations in each treatment. All analyses were carried out using the statistical STATISTICA 8.0 for Windows.

\section{Results and discussion}

\subsection{Population density of G. rostochiensis}

An average of $203 \pm 75$ cysts were found per $100 \mathrm{ml}$ soil in the experiment plots at the beginning of the experiment. This is in broad agreement with the results obtained by previous studies in the same community of Los Pescados,

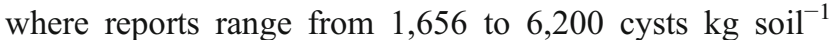
(Desgarennes et al. 2006; Núñez-Sánchez et al. 2003). At the end of the experiment, depending on treatment, the number of cysts had either fallen or remained constant $(127 \pm 51)$, and no significant differences were found between the four treatments. Nonetheless, the average number of cysts fell over the course of the experiment in the biological control fallow $(\mathrm{Tw}=0.0, N=10, P=<0.05)$ and fallow $(\mathrm{Tw}=10, N=10, P=<0.05)$ treatments.

The average cyst content at the beginning of the experiment was $12 \pm 6$ eggs and $\mathrm{J} 2 \mathrm{cyst}^{-1}$, with lower quantities of eggs and $\mathrm{J} 2$ per cyst in the biological control fallow (7.1 \pm $2.8)$ than in rotation $(16.2 \pm 3.5)$. The variation found in the content of the cysts in the crop fields at the beginning of the experiment is partly due to the fact that, of the eggs contained within cysts that had been in the soil for a longer period of time, as little as $2 \%$ may be viable while the cysts that had formed in the previous crop cycle could present $50 \%$ live eggs and juveniles (Desgarennes et al. 2006). For this reason, using the number of cysts to estimate population density of $G$. rostochiensis is inexact. Towards the end of the experiment, both the eggs and J2 contents of the cysts were reduced in the biological control rotation $(1.7 \pm 1.5)$ and biological control fallow $(2.2 \pm 1.6)$ treatments compared to fallow $(23.2 \pm 12.6)(H=14.45, N=20, P=<0.01)$. Moreover, the biological control rotation and biological control fallow plots presented reduced quantities of eggs and $\mathrm{J} 2$ per cyst over the course of the experiment $(\mathrm{Tw}=0.0, N=10$, $P=<0.05)$. In both of these biological control treatments, the content of the cysts was reduced by 86 and $68 \%$, respectively. This differs from the rotation plots, where the content of the cysts was reduced by $31 \%$ following two cultivation cycles. In contrast, the content of the cysts in the fallow treatment increased by $54 \%$. Our results from the rotation treatment plots concur with other studies that have shown populations decreasing by up to $40 \%$ after the second year of crop rotation in the absence of the host potato (Devine et al. 1999).

The average number of emerged J2 juveniles in the soil samples in all treatments was low at the beginning of the experiment $(5 \pm 4$ individuals per $100 \mathrm{ml}$ soil). At the end of the experiment, the lowest number of G. rostochiensis $\mathrm{J} 2$ juveniles was found in plots that had been treated with the nematophagous fungus (biological control rotation $=1 \pm 1$; biological control fallow $=0.2 \pm 0.4$ ). Of these, the number in biological control fallow was significantly lower than that of the rotation $(6 \pm 4)$ and fallow $(5 \pm 1)$ treatments $(H=14.7$, $N=20, P=<0.01)$. In rotation treatment, the number of $\mathrm{J} 2$ remained low throughout the experiment, which could indicate that the pea and bean crops utilized in the experiment did not stimulate the emergence of $G$. rostochiensis. In experiments carried out in the study area (unpublished data) in potato crop without any control, we found higher than $500 \mathrm{~J} 2100 \mathrm{ml} \mathrm{soil}{ }^{-1}$. This is in broad agreement with the results obtained by Brodie (1996) who reports 350 individuals $100 \mathrm{ml} \mathrm{soil}^{-1}$ in the presence of the host potato. Furthermore, in the treatments with biological control, we found on revision of the cyst interiors that the eggs and $\mathrm{J} 2$ were damaged, bound together by fragments of mycelia. In contrast, the eggs and J2 of the rotation and fallow treatments were found to be healthy. 
Mean infestation level recorded in the treatments at the beginning of the experiment was $2,147 \pm 957$ potentially infective individuals per $100 \mathrm{ml}$ soil. The effect of bionematicide application was seen in the biological control rotation and biological control fallow treatments from the fifth sample onwards (beginning of the second year of rotation) until the end of the experiment where infestation level was very low (Table 1). In biological control rotation, the infestation level was reduced by $89.2 \%(\mathrm{Tw}=0.0, N=10$, $P=<0.05$ ). In contrast, in the treatment rotation, it diminished by only $30.7 \%$, which was a non-significant difference with respect to the initial value (Fig. 2a). Related studies report that rotation with a non-host crop (Avena sativa) reduces the number of eggs $100 \mathrm{ml}$ soil $^{-1}$ by 30 $40 \%$; however, subsequent sowing of a susceptible variety of potato allows the population to recover (Brodie 1996). In some studies, it has been demonstrated that rotation with leguminous crops can achieve a population reduction of $G$. rostochiensis and Globodera pallida by between 25 and $30 \%$ (Iriarte et al. 1999; Pacajes et al. 2002). From the first crop cycle, potato plants growing from tubers remaining from the previous crops in our experimental plots were removed; however, we still had to remove potato plants during the second cycle. This was due to the large quantity of tubers that are left in the soil following harvest. For this reason, with these potato plants growing in the fields sown with non-host rotation crops, a certain amount of food was still available for the potato cyst nematode, which resulted in patches of high population density for the following crop cycle. Reduction of infestation level in the biological control fallow treatment was of $84.4 \%(\mathrm{Tw}=0.0, N=10, P=<0.05)$ relative to the initial values, while it was only $6.8 \%$, (Tw= 0.94, $N=10, P=<0.34$ ) in the fallow treatment (Fig. 2b). These results are in agreement with studies conducted in Bolivia, where leaving a soil fallow over one crop cycle produced a reduction of $11 \%$ in the infestation of Globodera spp. (Pacajes et al. 2002). The use of soil fallow periods and crop rotation as control methods for G. rostochiensis has not been effective because this nematode can survive for up to
20 years in the absence of its host (Evans 1993), and its population can still be viable after 10 years of cultivation of non-host plants or of soil left in fallow (Esprella et al. 1994). Similarly, the capacity of G. rostochiensis to survive in the soil in the absence of a host crop should not be underestimated, because it can reproduce in many wild host species that may be present in the cultivated area (Sullivan et al. 2007).

\subsection{G. rostochiensis multiplication rate}

The lowest multiplication rates were found in the treatments biological control rotation $(0.1 \pm 0.09)$ and biological control fallow $(0.15 \pm 0.09)(H=14.58, N=20, P=<0.01)$ (Table 1). Although the Pf/Pi reduced by more than $80 \%(\mathrm{Tw}=0.0$, $N=10, P=<0.05)$ in both the biological control treatments, it is more efficient to use the bionematicide along with crop rotation using non-host crops for two consecutive years. In studies using the fungus Pochonia chlamydosporia as a biological control agent in potato cultivation, a $\mathrm{Pf} / \mathrm{Pi}$ of 8.9 was obtained (Tobin et al. 2008). At the end of the experiment, a multiplication rate of $0.69 \pm 0.40$ was observed in the treatment rotation, similar to that found by Iriarte et al. (1999) and Pacajes et al. (2002) who recorded a multiplication rate of 0.7 with rotation of beans for 1 year. In our experiment, the highest $\mathrm{Pf} / \mathrm{Pi}$ was in treatment fallow $(0.93 \pm 0.25)$, but no significant differences were observed relative to the initial values $(\mathrm{Tw}=4, N=10, P=<0.34)$. Pacajes et al. (2002) found a multiplication rate of 0.89 after leaving soil in fallow for 1 year. For this reason, allowing soil to lie fallow without carrying out some additional form of nematode control is not an alternative in the short term for G. rostochiensis population reduction. From these results, we consider that control of $G$. rostochiensis should be conducted from the point of view of integrated management and requires the use of biological control with the rotation of non-host crops or with fallow periods at the same time, in order to lower the population density of the potato cyst nematode prior to the introduction of a new potato crop.

Table 1 Populations of Globodera rostochiensis by treatment (eggs and $\mathrm{J} 2 \pm$ standard deviation $100 \mathrm{ml} \mathrm{soil}{ }^{-1}$ )

\begin{tabular}{llccc}
\hline Treatment & $\begin{array}{l}\text { initial population density } \\
(\mathrm{Pi})\end{array}$ & $\begin{array}{l}\text { final population density } \\
(\mathrm{Pf})\end{array}$ & Pf/Pi & \\
\hline Biological control rotation & $1,878 \pm 444 \mathrm{a}$ & $181 \pm 130 \mathrm{a}$ & $0.10 \pm 0.09 \mathrm{a}$ & 89.2 \\
Rotation & $2,425 \pm 717 \mathrm{a}$ & $1,486 \pm 483 \mathrm{ab}$ & $0.69 \pm 0.4 \mathrm{a}$ & 30.7 \\
Biological control fallow & $1,671 \pm 577 \mathrm{a}$ & $240 \pm 134 \mathrm{a}$ & $0.15 \pm 0.9 \mathrm{a}$ & 84.4 \\
Fallow & $2,615 \pm 1602 \mathrm{a}$ & $2,145 \pm 526 \mathrm{~b}$ & $0.93 \pm 0.2 \mathrm{a}$ & 6.8 \\
$H$ & 2.65 & 15.33 & 14.58 & - \\
$P$ & 0.44 & $<0.01$ & $<0.01$ & - \\
\hline
\end{tabular}

Different letters in each column denote significant differences between treatments indicated by a multiple comparisons test

$H$ Kruskal-Wallis test $(P \leq 0.01), P f / P i$ nematode multiplication rate 
Fig. 2 Infestation level ( \pm standard error) at the start of each cultivation cycle and at the end of the experiment. a Biological control rotation and rotation treatments, b biological control fallow and fallow treatments
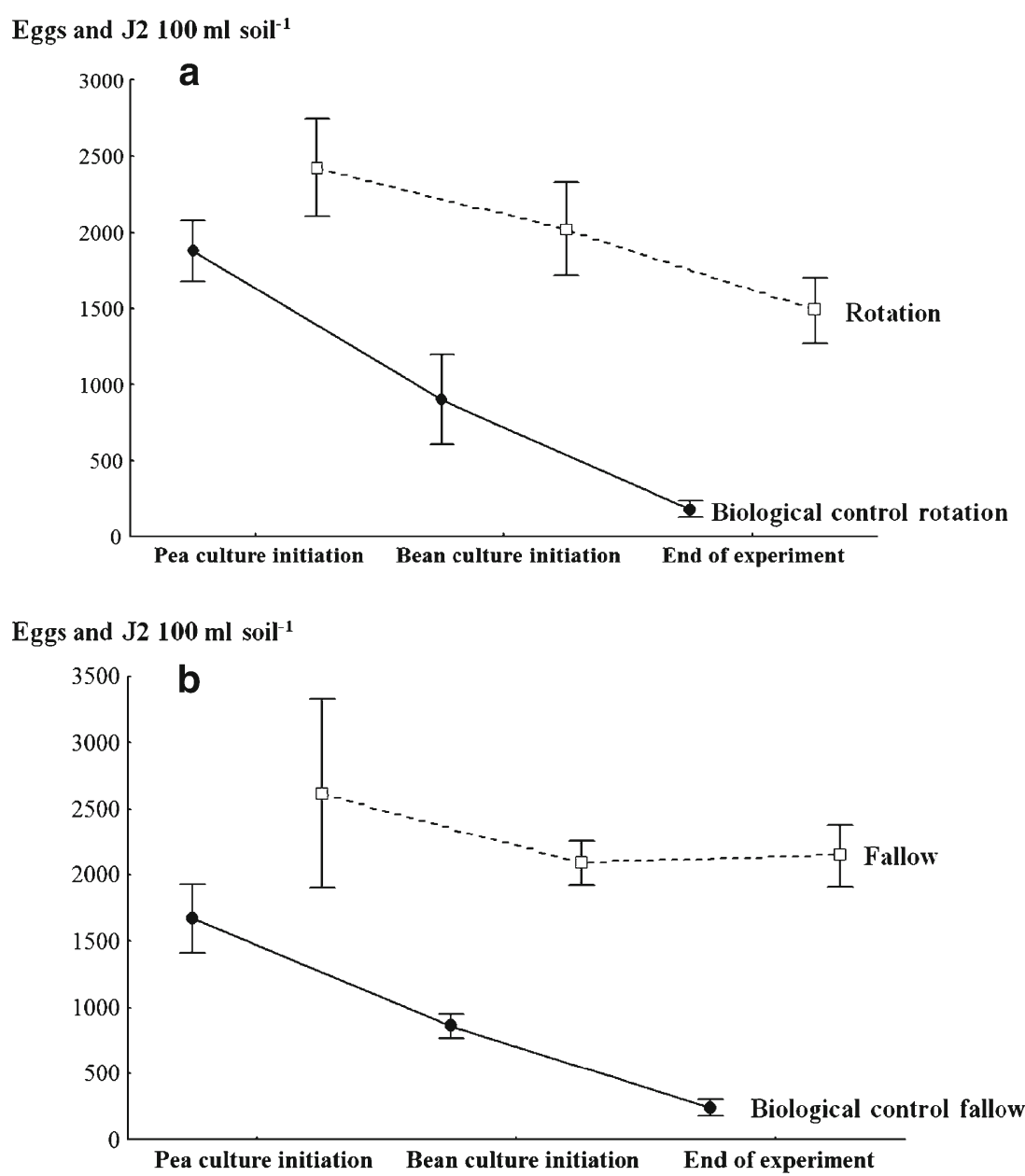

\subsection{Population density of free-living nematodes}

At the beginning of the experiment, $83 \pm 31$ free-living nematodes were recorded per $100 \mathrm{ml}$ soil. At the end of the second crop cycle, this number had increased in all treatments, with the exception of biological control rotation where the number had reduced by $23 \%$. The fungus used as a biological control agent against $G$. rostochiensis had no significant effect on the populations of free-living nematodes (Table 2). In general, the average number of free-living nematodes was lower in the plots with crop rotation than in the fallow plots, where the numbers increased by more than $200 \%$ in biological control fallow and fallow $(\mathrm{Tw}=0.0, N=10, P=<0.05)$. Thus, the lowest multiplication rate values were found in biological control rotation $(0.84 \pm 0.5)$ and rotation $(1.5 \pm$ $0.5)$. Conversely, the highest multiplication rates were found in biological control fallow (3.2 \pm 3$)$ and fallow $(3.7 \pm 2.1)$ $(H=7.83, N=20, P=0.04)$. The difference in Pf/Pi between

Table 2 Population of free-living nematodes per treatment (number of individuals \pm standard deviation $100 \mathrm{ml} \mathrm{soil}^{-1}$ )

\begin{tabular}{|c|c|c|c|c|}
\hline Treatment & $\begin{array}{l}\text { initial population density } \\
(\mathrm{Pi})\end{array}$ & $\begin{array}{l}\text { final population density } \\
(\mathrm{Pf})\end{array}$ & $\mathrm{Pf} / \mathrm{Pi}$ & $\%$ increase \\
\hline Biological control rotation & $105 \pm 23$ & $82 \pm 34$ & $0.84 \pm 0.51$ & -15 \\
\hline Rotation & $73 \pm 27$ & $117 \pm 70$ & $1.51 \pm 0.56$ & 51 \\
\hline Biological control fallow & $84 \pm 31$ & $212 \pm 184$ & $3.29 \pm 3.49$ & 229 \\
\hline Fallow & $70 \pm 37$ & $221 \pm 83$ & $3.78 \pm 2.17$ & 278 \\
\hline$H$ & 3.55 & 7.59 & 7.83 & - \\
\hline$P$ & 0.31 & 0.05 & 0.04 & - \\
\hline
\end{tabular}

Different letters in each column denote significant differences between treatments indicated by a multiple comparisons test

$H$ Kruskal-Wallis test $(P \leq 0.01), P f / P i$ nematode multiplication rate 
the biological control rotation and rotation treatments was $44 \%$, while the difference between biological control fallow and fallow treatments was $13 \%$ (Table 2).

This indicates that the tillage and sowing of the crop has an influence on the reduction of free-living nematode numbers, as has been shown in a study focused on tillage effects on soil organisms (Govaerts et al. 2006). In our experiment, no tillage or weeding in biological control fallow and fallow plots provided organic matter enough to increase free-living nematode populations. The susceptibility of these organisms to changes in their environment makes them potential bioindicators of soil conditions. The free-living nematodes play an important role in the agroecosystem through their participation in the decomposition of organic material and mineralization of nutrients in the soil as well as through their function as regulators of populations of fungi, bacteria, and insects (Bongers and Bongers 1998). For this reason, it is important that control methods for phytoparasitic nematodes do not significantly affect populations of free-living nematodes.

\section{Conclusions}

Biological control, in combination with rotation of non-host crops, can be a management strategy for the reduction of high populations of G. rostochiensis. We recommend the initial sanitizing of the soils in highly infected areas prior to sowing new potato crops. This strategy opens the possibility of rehabilitating and reactivating areas that are suitable for potato cultivation but are under quarantine at present. At the same time, the lack of impact on free-living nematodes by the biological control agent can still permit the biological diversity necessary for nutrient cycling. We have shown that the practice of leaving soils to lie fallow, while helping increase the diversity of edaphic organisms, is not a viable alternative for reduction of $G$. rostochiensis population density. The combination of both the strategies evaluated together in this study, namely that of biological control in conjunction with non-host crop rotation, was designed to reduce the population of potato cyst nematodes to thresholds of no economic significance at the same time generating a food product for human and/or animal consumption. These practices can be relatively easily incorporated by producers into the system of potato production that exists at present.

Acknowledgments This study is part of the results obtained in the project 0174936 funded by the Sectorial Innovation Fund (CONACyT) and conducted in the laboratory of Fungi Biodiversity and Systematics of the Instituto de Ecología, A.C. The first author is grateful for the support provided by CONACyT by provision of a grant (350758/ 238341) to carry out postgraduate study (Masters in Agriculture and Natural Resources) in the Universidad Autónoma del Estado de México. The authors thank Enrique Monfil for permitting the use of his property in Los Pescados and for help with the fieldwork. Grateful thanks also go to the technician Magda Gómez for her help in the laboratory.

\section{References}

Bongers T, Bongers M (1998) Functional diversity of nematodes. Appl Soil Ecol 10:239-251

Brodie BB (1996) Effect of initial nematode density on managing Globodera rostochiensis with resistant cultivars and nonhosts. J Nematology 28:510-519

Brodie BB (1998) Potato cyst nematodes (Globodera species) in Central and North America. In: Marks JR, Brodie BB (eds) Potato cyst nematodes biology, distribution and control. $\mathrm{CAB}$ International, Wallingford, pp 317-331

Cunha MJM, Conceição ILPM, Abrantes IMO, Santos MSNA (2004) Characterization of potato cyst nematode populations from Portugal. Nematology 6:55-58

Desgarennes D, Carrión G, Núñez-Sánchez AE, Núñez-Camargo MC (2006) Distribution of stages and in vitro larval hatching in Globodera rostochiensis cysts. Nematropica 36:251-260

Desgarennes D, Sánchez-Nava P, Peña-Santiago R, Carrión G (2009) Nematofauna asociada a la rizósfera de papas (Solanum tuberosum) cultivadas en la zona productora del Cofre de Perote, Veracruz, México. Rev Mex Biodivers 80:611-614

Devine KJ, Dunne C, O'Gara F, Jones PW (1999) The influence of inegg mortality and spontaneous hatching on the decline of Globodera rostochiensis during crop rotation in the absence of the host potato crop in the field. Nematology 1:637-645

EPPO (2009) Globodera rostochiensis and Globodera pallida. EPPO Bulletin, pp 354-368

EPPO/CABI (1996) Globodera rostochiensis and Globodera pallida. In: Smith IM et al (eds) Quarantine pests for Europe. CAB International, Wallingford, pp 601-606

Esprella R, Herve D, Franco J (1994) Control del nematodo quiste de la papa (Globodera pallida) por el descanso largo controlado comunalmente en el altiplano central Boliviano. In: Herve D, Genin D, Riviere G (eds) Dinámicas del descanso de la tierra en los Andes. IBTA-ORSTOM, La Paz, pp $175-183$

Evans K (1993) New approaches for potato cyst nematode management. Nematropica 23:221-231

Fenwick DM (1940) Methods for the recovery and counting of cyst of Heterodera schachtii from soil. J Helminthol 18:155172

Franco J (1994) Problemas de nematodos en la producción de papa en climas templados en la región andina. Nematropica 24:179-195

Govaerts B, Mezzalama M, Sayre KD, Crossa J, Nicol JM, Deckers J (2006) Long-term consequences of tillage, residue management, and crop rotation on maize/wheat root rot and nematode populations in subtropical highlands. Appl Soil Ecolog 32:305-315

Gurr GM, Wratten SD, Altieri MA (2004) Ecological engineering for pest management. CSIRO Publishing, Collingwood

Haydock PPJ, Woods SR, Grove IG, Hare MC (2006) Chemical control of nematodes. In: Perry RN, Moens M (eds) Plant nematology. CABI, Wallingford, pp 392-410

Iriarte L, Franco J, Ortuño N (1999) Efecto de abonos orgánicos sobre las poblaciones de nematodos y la producción de la papa. Rev Latinoam Papa 11:149-163

Lichtfouse E, Navarrete M, Debaeke P, Souchére V, Alberola C, Ménassieu J (2009) Agronomy for sustainable agriculture. A review. Agron Sustain Dev 29:1-6. doi:10.1051/agro:2008054

Mendes CAC, Mendes GE, Cipullo JP, Burdmann EA (2005) Acute intoxication due to ingestion of vegetables contaminated with aldicarb. Clin Toxicol 43:117-118. doi:I0.108I/CLT200050392

Núñez-Sánchez AE, Carrión G, Núñez-Camargo MC, RebolledoDomínguez O (2003) Densidad de población de quistes de 
Globodera rostochiensis Woll. en el Cofre de Perote, Veracruz, México. Rev Mex Fitopatol 21:207-213

Pacajes G, Franco J, Esprella R, Main G (2002) Efecto de diferentes cultivos y prácticas culturales sobre la multiplicación del nematodo quiste de la papa (Globodera spp.) en Bolivia. Rev Latinoam Papa 13:52-65

s'Jacob JJ, van Bezooijen J (1984) A manual for practical work in nematology. Landbouwhogeschool Wageningen, Wageningen

Secretaría de Agricultura, Ganaderia, Recursos Naturales, Pesca y Alimentacion (SAGARPA) (2002) Norma Oficial Mexicana NOM-40-FITO-2001 Requisitos y especificaciones para la producción y movilización nacional de papa comercial. Diario Oficial de la Federación, México

Seinhorst JW (1962) On the killing, fixation and transfering to glycerin of nematodes. Nematologica 8:29-32

Sobczak M, Golinowski W (2011) Cyst nematodes and syncytia. In: Jones J, Gheysen G, Fenoll C (eds) Genomics and molecular genetics of plant-nematode interactions. doi: 10.1007/978-94-007-0434-3_4
Sullivan MJ, Inserra RN, Franco J, Moreno-Leheudé I, Greco N (2007) Potato cyst nematodes: plant host status and their regulatory impact. Nematropica 37:193-201

Tobin JD, Haydock PPJ, Hare MC, Woods SR, Crump DH (2008) Effect of the fungus Pochonia chlamydosporia and fosthiazate on the multiplication rate of potato cyst nematodes (Globodera pallida and G. rostochiensis) in potato crops grown under UK field conditions. Biol Control 46:194-201

Tovar SA, Cid del Prado-Vera I, Sandoval JS, Martinez GA, Nicol JM, Evans K (2006) Los nematodos formadores de quistes en México. Rev Mex Fitopatol 24:145-151

Turner SJ (1996) Population decline of potato cyst nematodes (Globodera rostochiensis, G. pallida) in field soils in Northern Ireland. Ann Appl Biol 129:315-322

van Riel HR, Mulder A (1998) Potato cyst nematodes (Globodera species) in western Europe. In: Marks RJ, Brodie BB (eds) Potato cyst nematodes: biology, distribution and control. CAB International, Wallingford, pp 271-298 